\title{
Injectable promethazine: a risky drug of questionable efficacy
}

\author{
Miriam Cohen $^{1} \cdot$ Frank Stallone $^{2} \cdot$ Daniel J. Pallin $^{3}$
}

Published online: 13 April 2016

(c) Springer International Publishing Switzerland 2016

\section{Key points}

Parenteral promethazine poses an elevated risk of catastrophic tissue injury at the injection site

Parenteral promethazine is too risky for use in clinical practice

Safer antiemetic alternatives to promethazine should be used instead

Parenteral promethazine $\left(\right.$ Phenergan $\left.^{\circledR}\right)$ is a vesicant that can cause catastrophic tissue injury. As an antiemetic in the emergency department (ED) setting, its efficacy has been assessed in only one double-blind, placebo-controlled trial, which found no advantage relative to placebo [1]. Nevertheless, this agent is widely used in EDs in the USA. We suggest that parenteral promethazine is removed from hospital and ED formularies, due to the availability of multiple safe alternatives and the absence of evidence that undifferentiated nausea is mitigated by antiemetics in the ED setting [2, 3].

Vomiting was among the ten most frequent principal reasons for visiting an $\mathrm{ED}$, and accounted for 2,458,000 adult visits, according the 2011 National Hospital Ambulatory Medical Care Survey (NHAMCS): 2011 Emergency Department Summary Tables [4]. Promethazine was the

M. Cohen and F. Stallone: Retired, formerly clinical research scientist of investigational drugs in major pharmaceutical firms.

Frank Stallone

frankstallone.nc@gmail.com

1 New York, NY, USA

2405 Berryhill Drive, Carrboro, NC 27510, USA

3 Department of Emergency Medicine, Brigham and Women's Hospital, Boston, MA, USA third most frequently prescribed antiemetic drug in the ED, after ondansetron and diphenhydramine, in a count that combined all formulations including parenteral given in the ED, a take-home prescription, or both [4]. Sixty percent of patients who received promethazine got their first dose in the ED.

Injectable promethazine is a legacy drug that gained US FDA approval in 1956 when proof of efficacy was not required. Promethazine, a phenothiazine derivative, poses risks typical of the phenothiazine class. In 2006, the Institute of Safe Medicine Practices (ISMP) described injectable promethazine as a vesicant, which is "highly caustic to the intima of blood vessels and surrounding tissue", properties that have implicated it in numerous cases of catastrophic tissue injury at the injection site [6]. More recently, as part of its effort to draw attention to drugs judged likely to result in "moderate to severe patient outcomes when an error happens" [7], the ISMP conducted a survey of practitioners and safety experts throughout the USA [8]. Twelve "high-alert medications in acute care settings" were identified, based on the collective thinking of all who provided input in the survey. Intravenous promethazine is one of the 12 medications on the list, and the only antiemetic. The ISMP, in its assessment of how hospitals in the USA meet their obligations in dealing with high-alert drugs, recommends that special safeguards be put in place to minimize the risk of harmful errors posed by these 12 medications.

An FDA boxed warning advises that parenteral promethazine not be administered subcutaneously or arterially [5]; however, cases in which it was administered via a contraindicated route, with catastrophic consequences, have been reported, at least two of which were widely publicized [9]. The label revision reiterates the previous recommendation that intramuscular administration is the 
preferred route, and limits the allowed dosage and speed of intravenous administration [5], but stops short of disallowing parenteral administration.

In April 2000, Diana Levine, a professional musician living in Vermont, suffered an arm amputation after receiving an injection of Phenergan ${ }^{\circledR}$, the branded version of promethazine. The injection produced gangrene at the injection site, either because of an inadvertent intra-arterial injection or extravasation from an incorrectly performed venipuncture. In the course of the litigation of this widely publicized case, 20 previous cases of amputations resulting from promethazine injections were cited in the US Supreme Court briefs [9]. The acute pain after an injection error, and the trauma from experiencing necrotic tissue as it progresses in the ensuing hours, days or weeks, is made even worse when multiple amputations are required, as was the case for Ms Levine and others. The Supreme Court ruled in favor of the plaintiff and upheld the lower court's award of \$US6.7 million [9, 10].

Since the Supreme Court decision on the Levine case, numerous episodes of serious tissue injury from promethazine injections have been reported in the FDA Adverse Event Report System database, and in various medical [6, 11-14] and nonmedical publications [15-21]. The FDA has not published the number of episodes of serious tissue injury in its database. The total number is not known. However, the ISMP concluded that these events are "not rare" based on their survey of 989 healthcare professionals [22].

The adverse events at the site of injection cited in the injectable promethazine label [5] include "Severe chemical irritation and damage to tissues regardless of the route of administration. Irritation and damage can result from perivascular extravasation, unintentional intra-arterial injection and intraneuronal or peirneuronal infiltration. Adverse reactions include burning, pain, thrombophlebitis, tissue necrosis, and gangrene. In some cases surgical intervention including fasciotomy, skin graft, and/or amputation have been required." Additional adverse events reported in the warning section of the label include "burning, pain, erythema, swelling, sensory loss, palsies, paralysis, severe spasm of distal vessels, thrombophlebitis, venous thrombosis, phlebitis, abscesses, tissue necrosis, and gangrene." In effect, the label states that severe tissue injury might occur even if the recommended precautions are closely observed.

Nevertheless, the label still supports the use of parenteral promethazine as clinically appropriate. Results from placebo-controlled studies of women in labor [23], women undergoing total hysterectomy [24], and patients undergoing emetogenic chemotherapy [25] support the antiemetic effect of injectable promethazine. However, other antiemetic medications have been found to be safe and effective in the prophylaxis of post-operative nausea and vomiting (PONV). A multinational study of 4123 randomized surgical patients in 28 centers compared six prophylactic antiemetic strategies for the prevention of PONV in a 64-group factorial design: three antiemetic drugs (ondansetron versus none, dexamethasone versus none, or droperidol versus none); propofol versus a volatile anesthetic; nitrogen versus nitrous oxide; and remifentanil versus fentanyl. Ondansetron, desxamethasone, and droperidol (drugs that do not pose a risk of catastrophic tissue injury) each reduced the risk of nausea and vomiting occurring within $24 \mathrm{~h}$ after surgery by $26 \%$. Propofol reduced the risk by $19 \%$, nitrogen by $12 \%$, and fentanyl did not significantly reduce the risk. The investigators concluded that the safest or least expensive antiemetic should be used if antiemetic intervention is required [26].

The butyrophenone droperidol may be the treatment of choice because of its low cost [27]. Although its label carries a boxed warning regarding the risk of corrected QT (QTc) interval prolongation, that effect is not seen at the lower doses ( $<1 \mathrm{mg}$ or $15 \mu \mathrm{g} / \mathrm{kg}$ intravenously) used to control emesis and, in combination with ondansetron, the two drugs' antiemetic effects are additive, but their effects on the QTc interval are not additive [27].

In the most recent (2014) version of the Consensus Guidelines for the Management of Post-Operative Nausea and Vomiting [27], several antiemetic drugs are suggested as treatments for PONV if enhanced hydration alone does not produce an adequate treatment response. Promethazine is absent from the list because the evidence of its efficacy was deemed limited; its safety risks were also noted. The World Health Organization's Model List of Essential Medications included injectable promethazine for the last time in 2007, and has omitted it from subsequent biannual revisions of the list [28].

Some professionals have objected to removing injectable promethazine from their institution's formulary or even to taking greater precautions in its use, according to an ISMP survey conducted in 2006 [22]. However, the lack of efficacy in the treatment of undifferentiated emesis in the ED from a placebo-controlled trial is a recent and compelling new reason for concern about parenteral promethazine. Additionally, there are several safer antiemetics. The question of whether injectable promethazine, a legacy drug approved under relatively weak regulatory standards, continues to meet current standards for safety and efficacy should be re-examined by the FDA. Such action is in keeping with the Institute of Medicine's view that a "robust drug safety system requires a life cycle approach," a periodic review of the safety of a drug as its use in clinical practice evolves and new information becomes available [29]. 


\section{References}

1. Barrett TW, DiPersio DM, Jenkins CA, et al. A randomized, placebo-controlled trial of ondansetron, metoclopramide, and promethazine in adults. Am J Emerg Med. 2011;29(3):247-55.

2. Braude D, Soliz T, Crandall C, et al. Antiemetics in the ED: a randomized controlled trial comparing 3 common agents. Am J Emerg Med. 2006;24(2):177-82.

3. Egerton-Warburton D, Meek R, Mee MJ, et al. Antiemetic use for nausea and vomiting in adult emergency department patients: randomized controlled trial comparing ondansetron, metoclopramide, and placebo. Ann Emerg Med. 2014;64(5):526-32e1.

4. National Hospital Ambulatory Medical Care Survey: 2011 Emergency Department Summary Tables. http://www.cdc.gov/ nchs/data/ahcd/nhamcs_emergency/2011_ed_web_tables.pdf. Accessed 6 Jan 2016.

5. Institute of Medicine DailyMed list of all FDA-approved drug labels. http://dailymed.nlm.nih.gov/dailymed/index.cfm. Accessed 28 Aug 2015.

6. Action needed to prevent serious tissue injury with IV promethazine. ISMP Medication Safety Alert: Acute Care. 2006; Aug 10. www.ismp.org/newsletters/acutecare/articles/20060810.asp. Accessed 28 Aug 2015.

7. Your high-alert medication list-relatively useless without associated risk-reduction strategies. ISMP Medication Safety Alert: Acute Care. 2013; Apr 4. https://www.ismp.org/ newsletters/acutecare/showarticle. $\operatorname{aspx}$ ?id=45. Accessed 9 Dec 2015.

8. ISMP list of high-alert medication in acute care settings. https:// www.ismp.org. Accessed 9 Dec 2015.

9. In the Supreme Court of the United States, Wyeth, Petitioner v. Diane Levine, respondent. On Writ of Certiorari to the Vermont Supreme Court. Brief of Amici Curiae, former FDA Commissioners Dr. David A. Kessler in support of respondent. David C. Vladeck, Counsel of Record, Kathryn A. Sabbeth, Georgetown University Law Center, 600 New Jersey Ave., NW, Washington, DC 20001, Counsel for Amici Curiae. August 14, 2008. https:// supreme.justia.com/case/federal/us/555/555. Accessed $15 \mathrm{Sept}$ 2015.

10. Brueckner L. Impact of Wyeth v. Levine: high court refused to wipe out consumers' rights. American Constitution Society Blog. http://www.acslaw.org/acsblog/node/13033. Accessed 18 Aug 2015.

11. Sen S, Chini EN, Brown MJ. Complications after unintentional intra-arterial injection of drugs: risks, outcomes and management strategies. Mayo Clinic Proc. 2005;80(6):783-95.

12. Paparella S. The dangers of intravenous promethazine administration. J Emerg Nurs. 2007;33(1):53-6.

13. Foret AL, Bozeman AP, Floyd WE 3rd. Necrosis caused by intraarterial injection of promethazine: case report. J Hand Surg Am. 2009;34(5):919-23.
14. Paula R, Peckler B, Nguyen M, et al. Catastrophic complications of intravenous promethazine. Am J Emerg Med. 2010;28(4): 535.e1-4.

15. Frederich S. Malpractice allegations spotlight anti-nausea medication. Aberdeen, WA December 7, 2005. www.thedailyworld. com/articles/2005/12/07/local_news/02mews/txt. Accessed 28 Aug 2015.

16. Mahoney R. Woman's lawsuit: paramedic's error caused loss of arm. http://articles.orlandosentinel.com/2007-05-08/news/ARM08_ 1_volusia-county-mangan-paramedic. Accessed 28 Aug 2015.

17. IV Phenergan for nausea. Seems pretty routine, but not in this case. http://www.topix.com/forum/health/nausea/TIUD7E6T7B9 C2M4HU. Accessed 8 Sept 2015.

18. Knipe A, Staub S. Promethazine estravasation. https://prezi.com/ exyngyhjiboq/copy-of-promethazine-adr/. Accessed $12 \mathrm{Sept}$ 2015.

19. Lawrence J. What an outrage: court shields generic drug makers. AARP.org/bulletin, June 2012.

20. Foret AL, Bozeman AP, Floyd W. Necrosis caused by intraarterial injection of promethazine: case report. http://www. newscentralga.com//healthy/47533517.html. Accessed $12 \mathrm{Sept}$ 2015.

21. Thomas K. Generic drugs prove resistant to damage suits. New York Times, Wed. March 21, 2012, pp. A1 and 3.

22. Promethazine conundrum: IV can hurt more than IM injection! ISMP Medication Safety Alert: Acute Care. 2006; Nov 2. http:// www.ismp.org/newletter/acutecare/articles/200661102.asp. Accessed 28 Aug 2015.

23. Vella L, Francis D, Houlton P, et al. Comparison of the antiemetics metoclopramide and promethazine in labour. Brit Med J (Clin Res Ed). 1985;290(6476):1173-5.

24. Chia YY, Lo Y, Liu K, et al. The effect of promethazine on postoperative pain: a comparison of preoperative, postoperative, and placebo administration in patients following total abdominal hysterectomy. Acta Anaesthesiol Scand. 2004;48(5):625-30.

25. Buzdar AU, Esparza L, Natale R, et al. Lorazepam-enhancement of the antiemetic efficacy of dexamethasone and promethazine: a placebo-controlled study. Am J Clin Oncol. 1994;17(5):417-21.

26. Apfel CC, Korttila K, Abdalla M, et al. A factorial trial of six interventions for the prevention of postoperative nausea and vomiting. N Engl J Med. 2004;350(24):2441-51.

27. Gan TJ, Diemunsch P, Habib AS, et al. Consensus guidelines for the management of postoperative nausea and vomiting. Anesth Analg. 2014;118(1):85-113.

28. WHO Model List of Essential Medicines, 15th list, March 2007, http:www.who.int/medicines/publications/essentialmedicines/en/ index.html. Accessed 28 Aug 2015.

29. Baciu A, Stratton K, Burke SP, editors. The future of drug safety: promoting and protecting the health of the public. Washington, DC: National Academies; 2007. 